\title{
FIELD EVIDENCE CONCERNING THE ORIGIN OF EARLY PRECAMBRIAN GNEISSES AND AMPHIBOLITES IN PART OF THE FISKENÆSSET REGION
}

\author{
J. S. Myers
}

During GGU's first season of detailed mapping in the Fiskenæsset region south of Midgård in 1970, "the origin of the gneisses" ... was "much under debate" and it was concluded that "there is little evidence on which to decide whether they represent old granitic rocks or (in part) old metasediments" (Kalsbeek, 1971). In 1971, GGU's mapping on a scale of 1:20 000 was extended to the north-east of Midgård where, in an area of 100 square kilometres north of the head of Fiskenæsfjorden (fig. 3), it has been found that the gneisses are divisible into three main groups:

1. Naujât (amphibolite-banded) gneisses.

2. Kangeq (biotite- and pegmatite-banded) gneisses.

3. Qánguartoq (homogeneous and pegmatite-banded) gneisses.

The Naujât gneisses occur in the southern part of the area along the north side of Fiskenæsfjorden. They are amphibolite-banded gneisses characterised by alternations of amphibolite layers with quartzo-feldspathic layers each typically 2-5 centimetres thick. No evidence of their origin has been recognized.

The Kangeq gneisses occur to the north of the Naujât gneisses with apparently conformable relationships. They are more varied in character than the Naujât gneisses and typically are composed of an assemblage of biotite-banded gneisses, pegmatite-banded gneisses, diffusely biotite-banded gneisses and diffusely pegmatite-banded gneisses with smaller amounts of amphibolite layers and metasediments.

Amphibolite horizons up to 500 metres thick occur as concordant layers in the Kangeq gneisses and are the most prominent stratigraphic marker-horizons of the region. These amphibolites are finer grained than the gneisses and are composed of hornblende-plagioclase \pm clinopyroxene \pm biotite assemblages with small amounts of quartz and opaque minerals. They are typically either massive or weakly banded by variations in the abundance of leucocratic minerals and plagioclase-rich lenses containing garnet + sphene \pm scapolite arranged in layers. Some of these lenses contain remnants of large plagioclase crystals (about $\mathbf{A n}_{65}$ ), partial- 


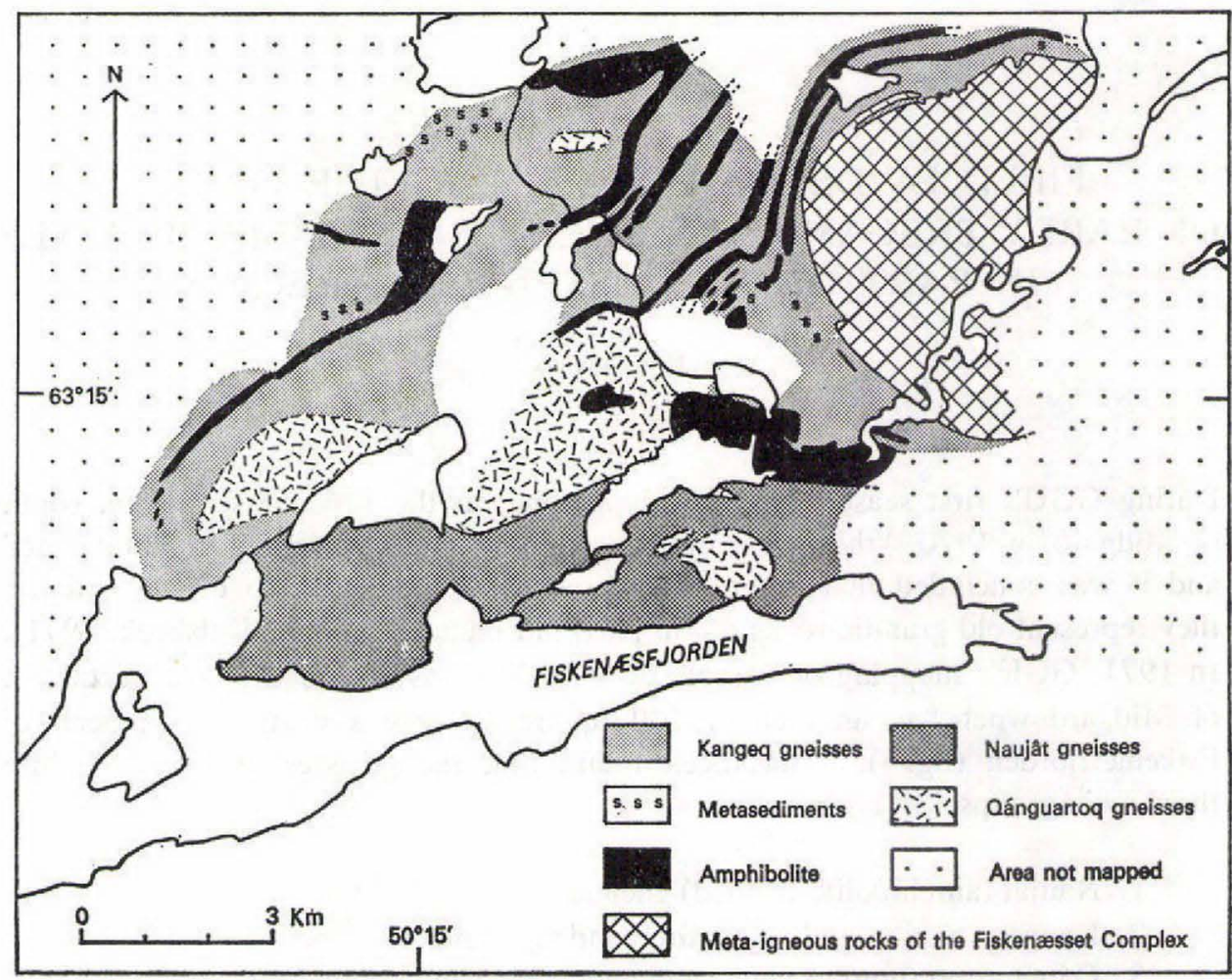

Fig. 3 Simplified map of the area north of the head of Fiskenæsfjorden showing the main rock units. (For location in the Fiskenæsset region, see plate 1).

ly recrystallised to finer grained, polygonal mosaics, and may represent primary feldspathic patches, such as xenoliths or phenocrysts in lava flows or sills.

Some of these major amphibolite horizons contain concordant layers of ultramafic rocks near one margin. Many banded amphibolite horizons also contain variable amounts of amphibolites with relict igneous mottling and of hornblendites both of which cut across the banding of the other amphibolites and enclose previously foliated and folded fragments of them. These amphibolites with relict igneous mottling and hornblendites are therefore clearly younger than the banded amphibolites. Metamorphosed layered leucogabbros, gabbros and ultramafic rocks of the Fiskenæsset complex occur as sub-concordant sheets within the banded amphibolites and also appear to be younger than them.

Layers and patches of metasediments occur within the Kangeq gneisses. The most distinctive rock types are impure quartzites and feldspathic quartzites containing various amounts of garnet, sillimanite and magnetite, either alone or in any combination, and diopside-hornblende-quartz-plagioclase rocks. The sillimani- 
te quartzites typically contain $60 \%$ of quartz, $20 \%$ of sillimanite and $10 \%$ of biotite with variable amounts of garnet. These impure quartzites pass along strike with complete gradation by loss of garnet and sillimanite and increase in feldspar/quartz ratio into typical biotite- and pegmatite-banded Kangeq gneisses, with variable but in many cases approximately equal amounts of quartz, plagioclase and potash feldspar. Interbanded with the quartzites occur homogeneous layers of quartz-plagioclase-biotite-garnet rocks up to 50 centimetres thick, with quartz and plagioclase in equal proportions and invariably containing small amounts of apatite and opaques, and thinner layers of quartz-sillimanite-biotite-garnet-plagioclase-potash feldspar rocks. The latter two rock types are more widespread in the Kangeq gneisses than the garnet and sillimanite-bearing quartzites, and rocks with similar appearance but lacking garnet and sillimanite are typical layers of the Kangeq gneisses.

The widespread occurrence of distinctive metasediments in the Kangeq gneisses suggest that many of the quartzo-feldspathic rocks of the Kangeq gneisses may also be derived from supracrustal rocks because of:

1. The complete gradation along individual layers from distinctive garnet and sillimanite-bearing feldspathic quartzites to quartzo-feldspathic gneisses.

2. The similarity between the typical kinds of layering of the quartzo-feldspathic Kangeq gneisses (homogeneous layers of quartz-plagioclase-biotite rock up to 50 centimetres thick and thinner and coarser grained layers of quartz-biotite-plagioclase-potash feldspar rocks) and layers interbanded with the quartzites (homogeneous layers of quartz-plagioclase-biotitegarnet rock up to 50 centimetres thick and thinner, coarse-grained layers of quartz-sillimanite-biotite-garnet-plagioclase-potash feldspar rocks).

It is not clear whether the thick amphibolite horizons originated as primary layers within the Kangeq gneisses or were intruded as sills at a later time but, because they occur only within the outcrop of the Kangeq gneisses and are absent from the Naujât gneisses, they appear to have a primary association with the Kangeq gneisses and therefore may also be of supracrustal origin. This conclusion is strengthened by the continuance southwards of similar amphibolite layers (Plate 1, Williams, Tomas, Andersen and Friend areas) into the Ravns Stor $\varnothing$ amphibolite belt where meta-pillow lavas are preserved.

The Qánguartoq gneisses occur throughout the area and include homogeneous and pegmatite-banded gneisses and gneissose and foliated granites and grandodiorites. Generally these rocks have been strongly deformed and are now fine-grained quartz-plagioclase-potash feldspar-biotite rocks (with percentage proportions of $40,30,25$ and 5 respectively), with planar fabrics which are concordant with the banding of the Naujât and Kangeq gneisses. However, in many places their outline cuts across both folds of the compositional banding and tectonic 
fabrics of the Naujât and Kangeq gneisses. Where these primary intrusive relationships are little deformed it can be seen that the emplacement of the Qánguartoq gneisses was accompanied in some places by boudinage and in other localities by extension in three directions which resulted in the formation of netvein complexes of granite and pegmatite in the Naujât and Kangeq gneisses and amphibolites and of stoping of angular blocks of these older rocks by the granite and pegmatite. All stages can be observed of the transformation by deformation and recrystallisation of the net-vein and stoped-block complexes into banded gneisses which in some places are difficult to distinguish from the older gneisses.

Foliated granites which appear to belong to the Qánguartoq gneiss group also occur within the large Majorqap qâva outcrop of the Fiskenæsset anorthosite complex where they cut across both the primary igneous layering and folded tectonic fabrics. The episode of intrusion of the Qánguartoq gneisses therefore appears to form the most widely recognisable time-marker in the deformation history of the area. The folded foliation of the Qánguartoq gneisses is cut by potash feldspar-rich pegmatite veins which are themselves cut by a minor group of meta-tonalites which were intruded both as small dykelets and sub-circular bodies up to 300 metres in diameter. The meta-tonalites were subsequently deformed, cut by a suite of pegmatite veins and were metamorphosed by the main regional metamorphism in amphibolite facies. In the western part of the area, the Qánguartoq gneisses contain hypersthene together with biotite and therefore appear to be older than the granulite facies metamorphism which affected the rocks in the vicinity of Fiskenæsset.

The main rock groups occur in this area of 100 square kilometres with the approximate proportions:

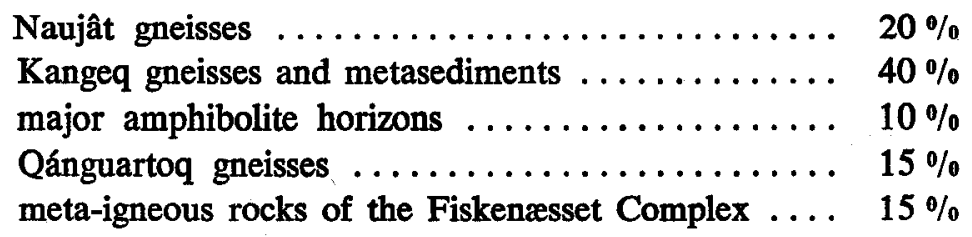

The Kangeq gneisses, metasediments and major amphibolite horizons appear to belong to one major group of rocks, chiefly of probable supracrustal origin. The Qánguartoq gneisses have been derived from a major group of instrusive granitic rocks and are younger than all the other main rock groups listed above.

\section{Reference}

Kalsbeek, F. 1971: Field work in the Fiskenæsset area. Rapp. Grønlands geol. Unders. 35, 17-18. 